\title{
DRAMA AS A TOOL FOR SOCIAL COMMENTARY: AN EXAMPLE OF ALEX ASIGBO'S THE REIGN OF PASCAL AMUSU
}

\section{Tochukwu J. Okeke}

\section{Abstract}

Drama has been widely acclaimed as a positive medium for mirroring society hence the popular cant that 'drama is a representation of life'. So, while drama entertains it also teaches and informs. This powerful attribute of drama has been employed by playwrights over the ages to make constructive commentaries on the happenings in society and thus affect some positive changes in man and his environment. This paper attempts an analysis of the playwright's use of drama to make comments on society using Alex Asigbo's 'The Reign of Paschal Amusu' as an example. We shall aim at exploring the use of drama to inform, educate and arouse the consciousness of individuals in society with a view of making them aware of their responsibilities as members of society whose duty it is to take their destinies in their hands and make the world a better place.

\section{Introduction}

The dramatist is the gadfly of his society. Socrates is quoted by Okafor as saying that a dramatist is "the gadfly which God has attached to the state and all day long in all places ..., am feasting upon you, arousing, persuading and reproaching you" (Ebo 2008: 108) Therefore, as the watchdog of society uses drama as a tool to affect changes in his environment through his works, the dramatist aims at showing how things stand in his own society (Obadiegwu 2002: 112) through his re-creation of events or in some instances by making postulations about the future. This is why the dramatist is sometimes referred to as a visionary because he deals 
with contemporary situations, and also functions as a visionary who utilizes recent experiences as perspective on both the present and the future. (Dandaura 2002: 179) Most dramatic works that aim at making caustic comments on society are known as satires. This is because satirical works aim at "hurting us so that we can amend." (Bamidele 2001: 40) The dramatist employs satire in his work to call the reader/audience to attention such that "even when we laugh, we see through the glen and reflect on our inadequacies." (Bamidele 40) Therefore, in using drama as a tool for social commentary, the artist is making an "objective evaluation, exposition or the critical assessment of the socio-political conditions in society." (Ebo 108). The dramatist is therefore a social commentator and a critic. Although some theatre scholars like James Ngugi see the satirical artist as one who is "standing aloof, to view society and highlight its weakness" they urge the playwright to "try to go beyond this, to seek out the sources, the causes and the trends" (1982:69). The effect of satirical works in society overtime cannot be underestimated. This is aptly captured by Hope Eghagha $(2006: 210)$ in the introduction on the potentials for popular theatre for national development thus:

Because popular theatre (drama) has the capacity to reach all strata of society using a simple language, a simple method, its outreach could be the tonic the nation needs for the change in values which both the leaders and followers of the country are currently clamouring for.

The dramatist is able to achieve this through his works because he is "a member of society so naturally his artistic sensibilities are shaped and sharpened by the socio-economic contradictions and political happenings of his time" (Dandaura 179)

Alex Asigbo, like most contemporary playwrights has lent his voice to the call for a just and egalitarian society through the lampooning of the Nigerian leadership, the corrupt system of governance and the ineptitude of the ruling elite. He has made an expose of the rot in our democracy and has joined other like minds in the call for a new vision.

\section{The Reign of Pascal Amusu As Social Commentary}

The Reign of Pascal Amusu is actually a depiction of the events that led to the transition from military to civil rule in Nigeria. While the playwright did warn that "characters portrayed in this drama are entirely the author's imagination and have no semblance whatsoever to characters living or dead" (Asigbo 2008: v) one cannot but liken the events portrayed in the play to similar occurrences in Nigerian society in the past decade.

The Reign of Pascal Amusu dramatizes the "Achille's Heel" of the Nigerian democratic institution which is the recycling of old, visionless and tired leaders by the already corrupt elite who see government and governance as their private inheritance. The practice has been to simply change the garb and nomenclature, from military Head of State in uniform to President of the Federal Republic in flowing agbada. We therefore see in the characters presented to us overtly ambitious and selfish lot who would readily ridicule education and merit but eulogize mediocrity and avarices. According to SASHA:

SASHA... Walahi there was an election but Masi for reasons best known to him cancelled the election and sacked the chairman of the election committee. Sowole goes to town making trouble ...I mean duty is duty. I drove Sowole and his gang into exile. Walahi, they don't have right to demand that I hand over to Shiwo. Did I do the selection? Did I watch over the selection? Walahi, I will do my own selection and I will select myself by 


\section{consensus.......(2)(where Sowole is a renowned Professor)}

This paints the picture of a nation adrift in tumultuous waters; where the country's best brains are forced into exile while near nitwits steer the affairs of state. Through the use of simple conversational language interspersed with indigenous exclamations Asigbo has driven home the point that our leaders are egocentric, myopic, selfish and crude as can be seen from the following statement by AMUSU.

\section{AMUSU:...and I am a man of destiny. But seriously things have decayed in this country. All the infrastructure I left during my last reign have all degenerated... and to make matters worse, all these criminal rulers that came after me have looted the treasury of the nation to stupor. Just imagine... Masi ole nie. Shasha, big time barawo and even Salam... that one is a smooth criminal.... \\ That man almost had me I tell you! Can you imagine? He started bringing up the issue of a communications contracts we did back in the 70s when I asked him to refund some money ... and to add salt to injury, he insists that I must hand over to him at the expiration of my tenure Anyway that will be over my dead body (13)}

The above statement made by the President of a country gives the impression of a power drunk dictator inherently vindictive. Someone who is not interested in the progress of the land he is in charge of but is rather carried away by the appurtenance of power and is bent on perpetuating himself there thus:

\section{AMUSU: And let me warn all of you ... I may not know who will succeed me, but I definitely know those who will not succeed me. (24)}

One gets an impression of a leader who has ascribed to himself a godlike disposition. He supposedly possesses the power to determine the fate of his subjects not minding whose ox is gored.

While Asigbo may have succeeded in making the reader laugh through the fluidity of language, the unemotional manner he presented the demise of SASHA makes the reader laugh through tears while thinking about the future of the country.

\section{EL-GHANDI: Oh my commander ... anyway, they said it is in the interest of the fatherland.}

SALAM. Oh Sasha, so this is how you ended up? well, well, well. A tear for you...

This poses a big moral and social question both to the rulers, the ruled and potential leaders. It is this desperation for power, (where a country's first citizen is supposedly killed "in the interest of the fatherland") that has put Africa still in her developmental state. Similar trends like this abound in the nation's history. All these, the dramatist has put across using dark comedy such that by using this "comic method of attack" he could lull and ingratiate "even those most under fire so that they are caught with their defenses down" (Bamidele 19)

As the play progresses, one sees AMUSU's desperate bid to perpetuate himself in power and with the promise of installing his aide as the governor of a state not minding the feelings of the people to be governed This calls to mind the excesses of one of Nigeria's past rulers. 
AMUSU: You see what I mean?

We own this country .In fact, Odibo, For serving me diligently these past years I am going to make you governor of your state whether your people like it or not (26)

Then from this inglorious attempt at foisting an unpopular candidate on a people came the idea of installing a sick stooge to succeed him as president. The dialogue below explains this:

SONY: $\quad$ My leader, there's fire on the mountain

AMUSU: Fire on the mountain?

SONY: Yes our anointed candidate collapsed while addressing a crowd of supporters

AMUSU: Really?

SONY: Yes

AMUSU: He's not dead, is he?

SONY: We have not confirmed that yet your Excellency

AMUSU; Well, there's nothing to fret about whichever way it goes, we're not losing I mean, it's not as if we didn't know that he's not as fit as a fiddle when we chose him (37-38)

This paints a clear picture of the ineptitude of some leaders who out of their personal interest would sacrifice the future of the nation, even that of future generations, on the altar of ego centredness. Asigbo has given a picture of an unfeeling ruler, a despot if you like. One who can go to any length to hound his opponents, even those that make very constructive criticisms about the government.

As the play ends with the escape of Amusu and Odibo, Asigbo leaves a big question mark in the mind of the reader. Why would such bad leaders always escape the law? Has the dramatist resigned to fate that ours is a failed state and that there is no respite in sight?

A more critical appraisal of the work shows that the dramatist may not have given up on the struggle to fight the ills militating against the attainment of a just society, but like most satirical playwrights he believes in the "moral function of satire as an instrument for exposing folly and vice and for correcting all those deviations from the standards he upheld" ( Bamdele:19)

Asigbo therefore, has succeeded in raising the people's consciousness to an awareness of the rot in the nation. Thus, the laughter one enjoys while reading The Reign of Pascal Amusu can well be "re-defined as laughter in tears, black laughter ....clownish mirth ... (Bamedele.31) In fact, the playwright has succeeded in arousing in the reader "not merely interest or excitement, pity or amusement but to probe the complicated interrelation of character and action in a situation admitting of different ethical interpretation" (Bamidele 31-32). In other words, the playwright has raised some moral questions about the individual as well as society. The onus is on the reader to seek answers to those questions.

There is yet another salient point in the play which is the use of music. Music in drama is employed to embellish the theme, to serve as interludes and in some instances pass comments on ongoing actions in order to move the plot forward. In Asigbo's use of Fela's Unknown Soldier and ITT, both satirical songs of one of Nigeria's most vociferous social critics, he passes a ribald comment on the nature of our rulers. SASHA became a victim of his own game and AMUSU is neck deep in corruption which he professes to fight As one recollects the lyrics of these songs, the song in Wole Soyinka's Opera Wonyosi "who killed Neo Niga" (1988: 342-343) comes to mind. These are commentaries African, nay Nigerian dramatists have been able to make on society in their positions as the watchdogs 
championing the cause for a positive change.

\section{Conclusion}

Thus far we have attempted an analysis of the play The Reign of Paschal Amusu to show how drama is used as a tool for social commentary and have been able to establish the fact that "playwrights the world over use their works to show the ills inherent in their society" (Ebo 109) and Sofola is quoted by Odiri (2006:251) as saying that the artist is "one who is an embodiment of truth, sound morals, articulate and upright, a gadfly of society and one who strives at all times to warn society whenever is adrift". Asigbo has tried to live up to this billing. He has attempted to meet the societal expectation of the dramatist where he is expected to live

up to his iconoclastic stance, resolved to confront adroitly the cruelty, the physical violence, the autocratic methods of administration, the subjugation of women, the 'eye service' nature of 'powers that be' and all sorts of uncivilized customs and manners which started creeping into society (Bamdele 37-38).

Therefore, from this study of The Reign of Pascal Amusu, it has become obvious that the playwright can employ drama as an effective tool for social commentary. The artist has used this medium to highlight "... the value system of a society, for the purpose of enlightening, educating and motivating the people" (Utoh-Ezeajuh 2003: 11-12). This is more aptly captured by Obadiegwu when he asserts that:

A writer must be in tune with the politics of his nation $\mathrm{He}$ must penetrate the deep social political terrain of his nation in order to lay bare the inherent contradictions that encapsulate society. (2003:94)
The self succession syndrome and planting of stooges that successive rulership in Africa has used to hoodwink and beguile society is laid bare by the dramatist as one who has penetrated the "deep social political terrain of his nation". It is left to the reader to take up the baton which drama has held up to search and get a solution to the ever ending dearth of selfless leadership in Nigerian society.

\section{Works Cited}

Asigbo, Alex: The Reign of Pascal Amusu. Awka: Valid Publishing Company, 2008.

Bamidele, Lanre O. Comedy Essays and Studies. Ibadan: StirlingHorden, 2001.

Dandaura, Emman .S. "Hagher: The Playwright Documentarist as a Nation Builder". Theatre Experience. vol.1 no. Awka: Penmark Publishers Inc, 2002. 177-194

Ebo, Emmanuel E. "Social Criticism in Nigerian Drama: A study of Wole Soyinka's Opera Wonyosi" Applause: vol 1 No 4. Enugu: AcademicPublishing Co., 2008. 107-119

Eghagha, Hope. "Popular Theatre and its Potential for National Development" African Arts And National Development Sam Ukala ed. Ibadan: Kraft Books, 2006. 212 - 221

Ngugi, James "Satire in Nigeria" Protest and Conflict in African Literature. Pieterse Cosmo \$ Munro Donald ed . London: Heineman Educational Books, 1982. 56-69

Obadiegwu, Cyprain.O. "Satire and the Politics of a Viable Alternative: The Example of Ola Rotimi's If: a Tragedy of the Ruled" Theatre Experience vol 1. Awka: Penmark Publishers Inc, 2002. 112121

Obadiegwu, Cyprain.O " The Search for Ideal Leadership and the Evolution of Rotimi's Dramatic Heroism" Theatre Experience vol 2 no1. Onitsha: Koly, 2003. $94-102$ 
Odiri, Solomon E "Theatre in Nigeria and National Development" African Arts and National Development Sam Ukala ed Ibadan: Kraft Books, 2006. 251-260.

Soyinka Wole: Opera Wonyosi Ibadan: Spectrum Books, 1988. Utoh-Ezeajuh, Tracie. "Dramatizing a People's History as a Parable for a Nation in Search of Peace: Alex Asigbo's Duology as Paradigm." Theatre Experience. Vol 2 No 1. Onitsha: Koly Computer House, 2003. 10-17. 